\title{
連続静止画像に基づく島田川河口部における 地形変動特性の分析 \\ INVESTIGATION OF DYNAMIC MORPHOLOGY CHANGE AROUND THE SHIMADA RIVER MOUTH BASED ON ANALYSIS OF SUCCESSIVE STILL CAMERA IMAGES
}

\author{
田島芳満 1 -丹治雄一 2 - 三宅健一 ${ }^{2}$ - 加藤広之 ${ }^{2}$ - 中山哲嚴 ${ }^{3}$ \\ Yoshimitsu TAJIMA, Yuichi TANJI, Kenichi MIYAKE \\ Hiroyuki KATO and Akiyoshi NAKAYAMA
}

\author{
1正会員 Ph. D. 東京大学大学院 社会基盤学専攻（干113-8656 東京都文京区本郷7-3-1） \\ 2正会員 （財)漁港漁場漁村研究所（干101-0047 東京都千代田区内神田1-14-10） \\ 3正会員 工修 (独) 水産総合研究センター水産工学研究所（†314-0408 茨城県神栖市波崎7620-7）
}

\begin{abstract}
This paper aims to develop an image-based sensing system that enables us to monitor the time-varying shallow water bathymetry near the shore and apply it to monitoring of dynamic morphology change around the Shimada river mouth. Field camera, installed near the river mouth, recorded still images with time intervals of two seconds. Local housing conditions of the camera may slightly change its locations and angles. The developed system thus first rectifies such finite changes of the still image and then yields the top-view-images of the river mouth based on the local XY-coordinate systems. Spatial locations of the "shoreline" are then extracted from these images each of which were taken at different tide levels. The sea water level around the river mouth was directly measured by a pressure sensor installed just outside the river mouth. Combinations of these "shorelines" at different tides finally yield threedimensional bathymetry data. Obtained morphologies around the river mouth were finally compared with changing external hydrodynamic conditions such as waves, tides and river flows.
\end{abstract}

Key Words : River mouth, image-based monitoring, image rectifications, sand spit

\section{1.はじめに}

山口県光市虹が浜の東端に注ぐ島田川の河口部で は，沖まで直線的に延びた堤防で左岸が固定され， その遮蔽域に位置する河口右岸側では，左岸に向 かって砂州が伸びている。河口砂州周辺の水深は開 口部を除いて浅く，平常時の来襲波浪は比較的静穏 である。そのため，河口砂州形状は比較的安定であ るが，それでも上流から供給される土砂や河川流， 潮汐などの影響を受け砂州はゆっくりと変動しなが ら発達しているようである。河口砂州を含む河口テ ラス周辺の堆積土砂を周辺海浜へと供給することは, 周辺海浜の侵食問題の緩和や島田川自身の内水の排 水能力の確保といった観点で本質的に重要であると 考えられるが，島田川河口域では深浅測量データの 蓄積が十分ではなく, その変形特性は明らかになっ ていない.

本研究では, 大潮時の潮位差が約 $3 \mathrm{~m}$ ある対象地 点の特色を生かし, 定点観測カメラに基づき島田川 河口域における砂州周辺地形を高頻度で捉え，その
変形特性を解明することを目的とする。ここで開発 する観測システムは，潮位差のある遠浅な海岸では 特に有効であり, 本研究では汎用的なシステムを構 築することも大きな目的のひとつとして位置づける。

\section{2. 調査の概要}

島田川河口部における観測機器設置位置を図-1に 示す. まず水位と流速との関係を把握する目的で, 2010年5月10日から 12 日にかけて電磁流速計と波高 計を河口砂州周辺部に設置し(図-1, 水圧式波高計 は地点 1 , 2および4, 電磁流速計は地点2 24$)$, 時々 刻々の水位および流速を 0.5 秒間隔で記録した。次 に河口右岸側に位置する生コンクリート工場のプラ ント最上階にある屋外テラスの手すりに定点観測力 メラを設置し(図-2), 河口周辺の状況を2秒間隔で 連続撮影した。観測対象期間は台風に伴う出水や比 較的大きな波浪が来襲することが予想される2010年 7月 15 日から同年10月末までとした。またこの期間 


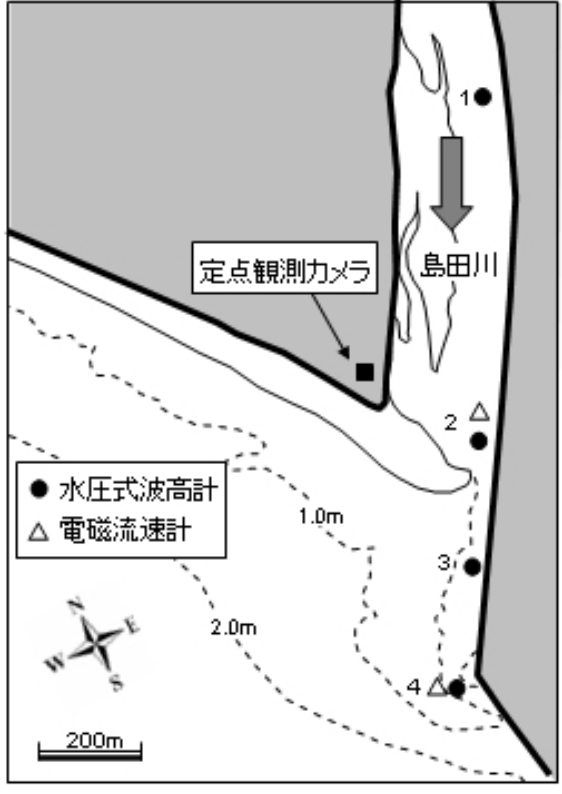

図-1 島田川河口域における調査の概要

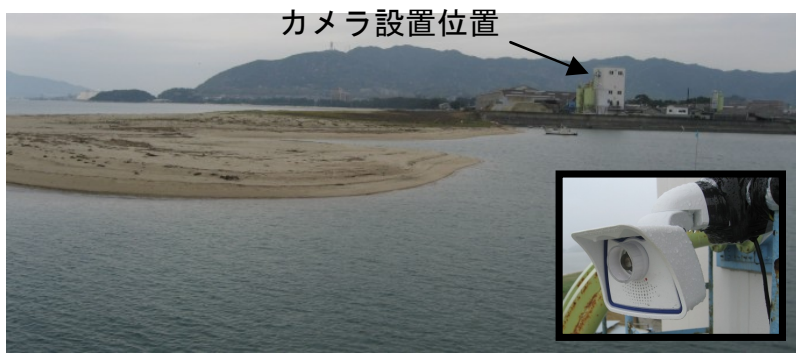

図-2 定点観測カメラの設置位置と設置状況

には，撮影対象である河口部における平均水位を計 測する目的で，河口左岸側 (図-1の地点3)に水圧式 波高計を設置し，1秒間隔で水圧 (水深)を記録した。 波高計の設置直後には水面高さを測量し, 波高計に よる計測值を基準高さ (CDL) に基づく水面高さを推 定した。

\section{3. 河口部周辺における潮汐応答特性}

図-3に波高計および流速計で記録した水位および 流速成分 (南北，東西方向成分) の時間変化を示す. 図に見られるように，河口砂州の上流側 (地点2) と 下流側 (地点4)における水位差は数 $\mathrm{cm}$ 程度で, その 波形は，地点 2 におる南向き(流下方向)流速成分 の波形と変動のタイミングが一致している。このこ とから，地点2から4への流下抵抗はほぼ河口狭窄部 周辺での周囲よりも速い流速 (ここでは最大 $50 \mathrm{~cm} / \mathrm{s}$ 程度)に起因しているものであることが推察される。 また，上げ潮時の水位差の変化は下げ潮時のそれに 比べて急激に変化しており, 比較的上下に対称な潮 位変化に対し, 水位差や流速は非対称な挙動を示し ていることがわかる。また地点 2 における南向き流 速は下げ潮時に最大となった後ゆっくりと減少し,

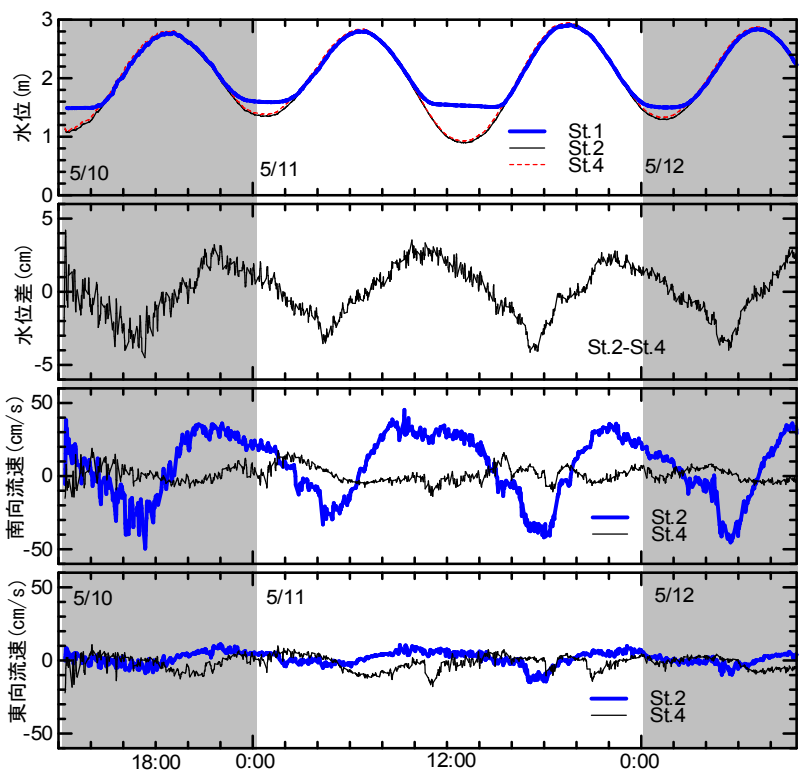

図-3 島田川河口における水位および流速の観測結果 (2011年5月 10 日～12日）

上げ潮から満潮にかけて最小值 (負の值)をとる。す なわち，流れは北向きとなっており，河川流量が少 ない条件下では，島田川河口部で逆流することが分 かる.

次に，地点 1 と 2 水位変動の違いに着目すると, 両者には干潮時に特に有意な差が見られ, 地点 1 で 干潮時に観測した水深の最小值は約 $47 \mathrm{~cm}$ であった。 干潮時には水深が小さくなり底面摩擦抵抗が増大し たことが推察される.

次に，定点観測カメラによる沿岸域監視を実施し た2010年7月から10月末までの約3ヶ月間における河 口狭窄部下流側 (地点3)に設置した波高計による計 測結果を整理する。ここで得られるデータは，後述 する定点観測カメラ画像による，等深線コンター位 置の推定に用い，また同時に，この等深線の時間変 化に寄与する外力場を推定する目的にも用いる。 そ のため, ここでは，10分間で平均した潮位 $\eta_{\text {mean }} に$ 加え, 平均水位から標準偏差 $\eta_{\mathrm{rms}}$ をそれぞれ算出し, その時間変化を示した (図-4). さらに, 潮汐に伴う 水位変動と, 河川流量や高波浪下のwave setupなど の潮汐とは関係ない因子に伴う水位変動とを分ける 目的で，調和解析に基づき推定した水位と実測水位 との差を合わせて図示した。調和解析には注目する 時間の前後 5 時間，合計 10 時間の值を用いた。得ら れた水位の差分は， $\eta_{\mathrm{rms}}$ の増加や同時に図示した大 松地点における日降雨量と連動しているように見え る。ただし， $\eta_{\mathrm{rms}}$ はせいぜい $10 \mathrm{~cm}$ 程度であり，観測 期間中の来襲波浪は概して小さかったといえる.

\section{4. 画像解析による等深線データの抽出}

図-4に示したように，島田川河口部では大潮時の 潮位差は $2 \mathrm{~m}$ 以上になる。この特性を利用し，定点観 


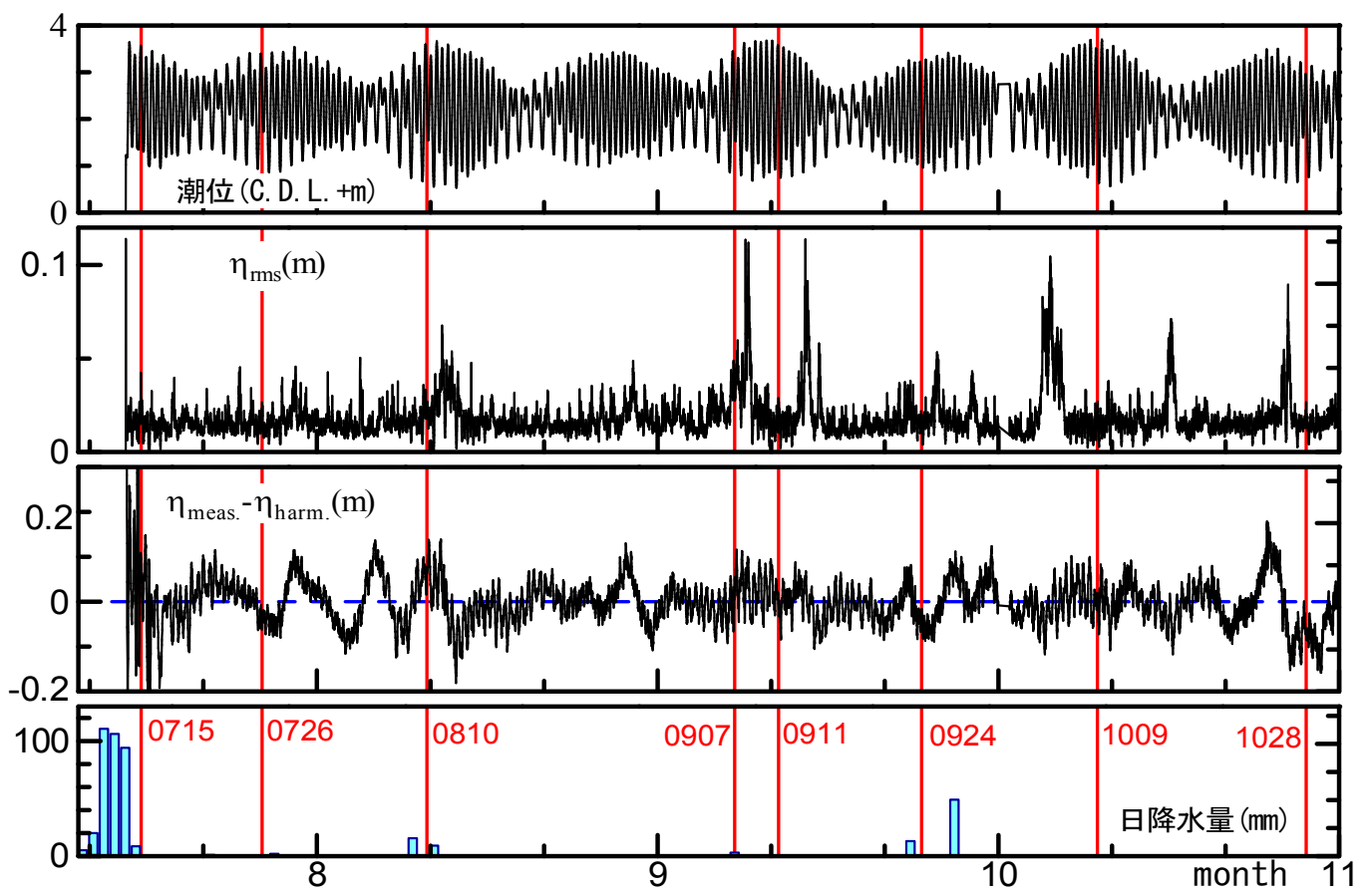

図-4 島田川河口部地点 $3 に お け る$ 観測結果 (10分間の平均水位，標準偏差，10時間の水位デー夕に対する調和解析に 基づく水位の推定値と実測値との差，日降雨量）

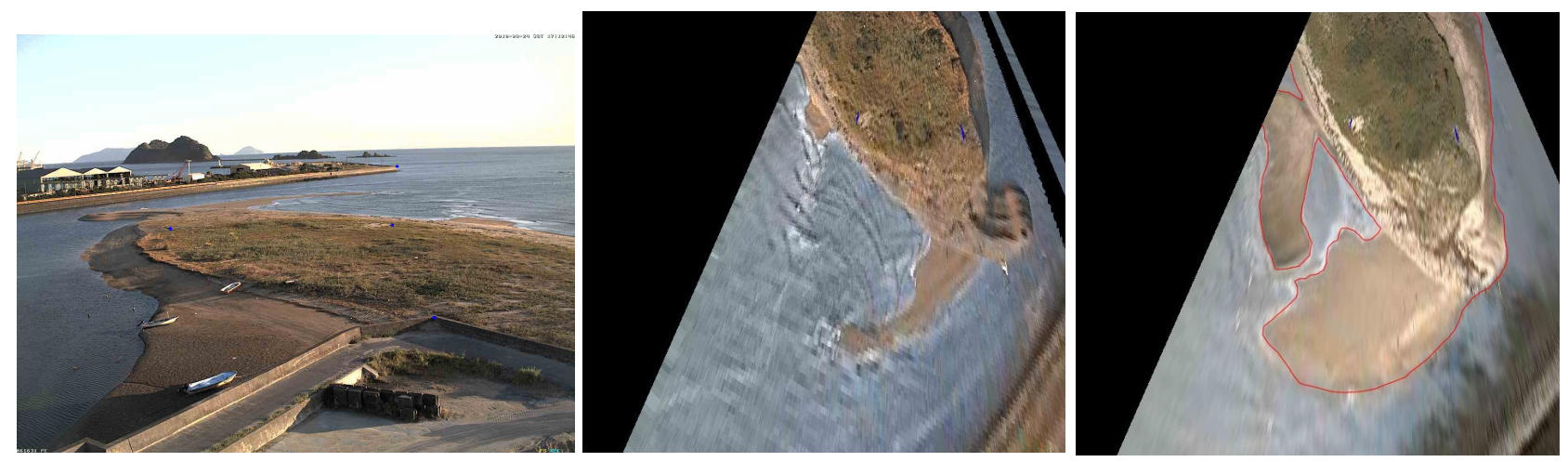

図-5 定点観測カメラにより撮影した原画像(左)および座標変換後の平面直角座標に基づく画像(中央および右). 図中の青点はカメラ位置およびアングルの矯正に用いた基準点位置，赤線は汀線抽出位置.

測カメラ画像から等深線位置を抽出し，砂州の三次 元的な形状変化のモニタリングを試みる。まず，基 準とする定点観測カメラ画像を選定し，画像内にお いて特徴的な基準点 10 点を選定した。これらの基準 点の選定時には，これらの点が画像内にバランスよ く分布すること, 実際の平面座標および標高もバラ ンスよく分布すること, さらに，画像内で容易に判 別可能であることなどを選定条件とした．次に選定 した10地点における平面直角座標をGPSを用いて計 測した。これらの基準点情報に基づき, 田島ら （2008）と同様の手法を用いて画像の座標変換を行い, 平面直角座標に基づく画像へと変換する.

ここで，上記の手続きに従い座標変換のためのカ メラ位置やアングルなどのパラメタを抽出してしま えば，同じ条件で撮影した画像については，同じパ ラメタに基づき座標変換を行うことが可能である. しかしながら, 実際の長期間の定点カメラ観測では
潮汐や風，カメラハウジングの状態など，様々な要 因に伴うカメラの設置場所やアングルが微小に変化 することがある. 本研究においてもカメラ画像が ゆっくりと微動していることが明らかとなった。

このため, 本研究では別に設定した4点の基準点 に基づき, 任意の取得画像の画素配置を基準画像の それへと自動的に変換するシステムを構築した。こ のシステムでは，選定した 4 つ基準点位置を画像上 で予め青い点でマークを付しておき, マークした点 の画素座標を自動的に読み込み，この座標が基準画 像の画素座標と一致するように自動的に座標変換を 行った。この手法を用いることにより, 座標変換後 の画像は基準とする画像と効率よく一致させること が可能となった。図-5に, 原画像と座標変換後の画 像を示す.

最後に得られた画像から水際線(等高線) 位置を抽 出し, 一潮汐間の画像群から抽出した異なる等高線 
を用いて砂州周辺の等高線図を作成した。まず，座 標変換した画像上における水際線位置を画像描画ソ フトを用いて赤線で描き込み(図-5右), 得られた画 像のRGB情報に基づき赤線の画素座標を抽出した. ここで得られた画素座標は既に平面直角座標系に基 づいているため, 汀線位置の平面直角座標が直接抽 出できたことになる.

以上の操作により得られた島田川河口周辺部にお
ける等深線図を図-6に示す。等深線図の抽出期間は 2010年7月 15 日から10月30日までの3ケ月半であり, 等深線を抽出する画像の選定条件としては, まず潮 位がCDL+0.6mから $3.3 \mathrm{~m}$ での $30 \mathrm{~cm}$ 間隔で区切った各 潮位に達した時の画像を対象とした。さらに，水位 の観測データに基づき, 一潮汐の間にこれらの代表 潮位 $(\mathrm{CDL}+0.6 \mathrm{~m}$ から $3.3 \mathrm{~m}$ までの10潮位)のうち，8潮 位以上を含んでいる日のみを選定した。これにより，
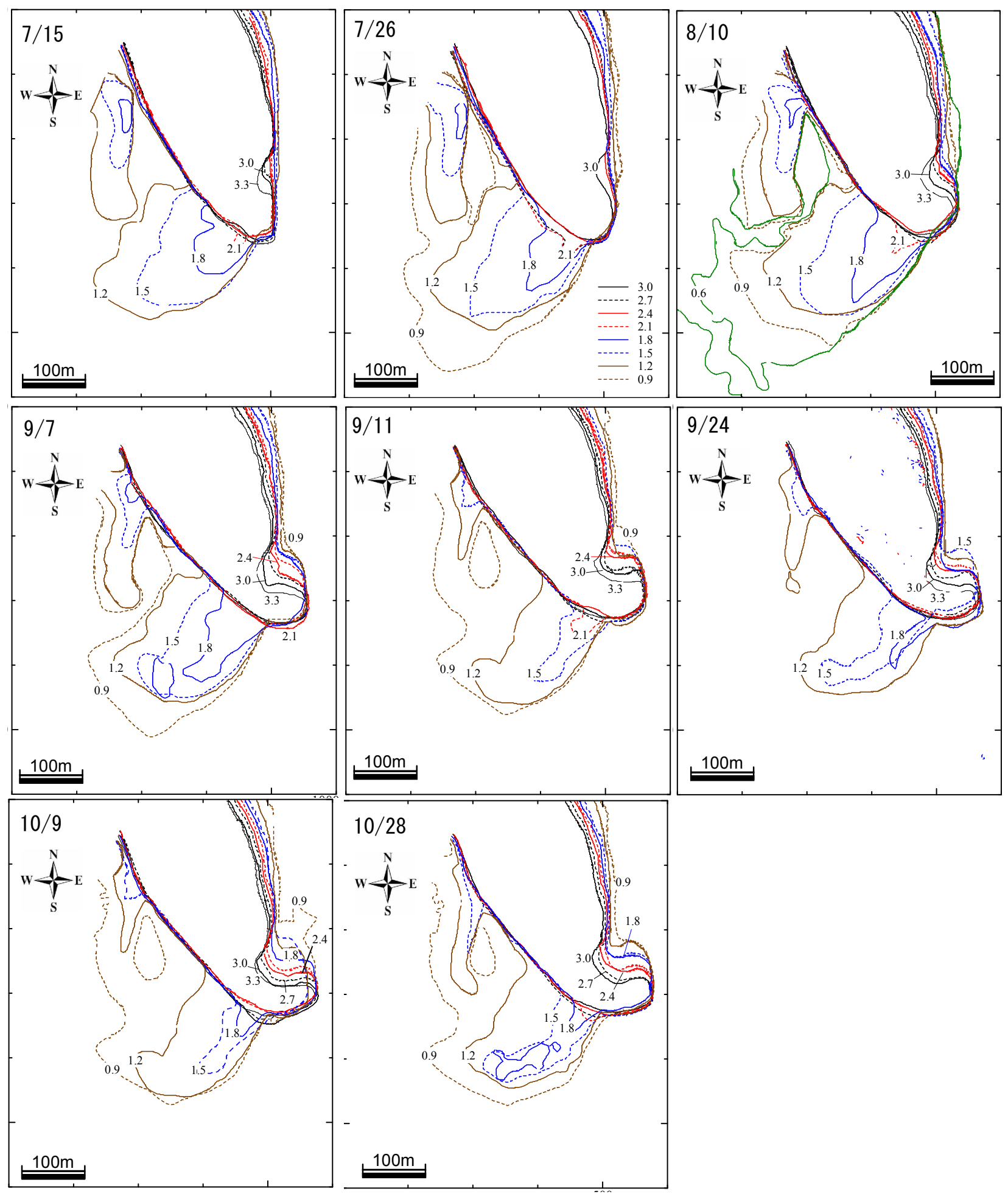

図-6 抽出した等深線図の比較 (2010年7月 15日〜10月 28日) 

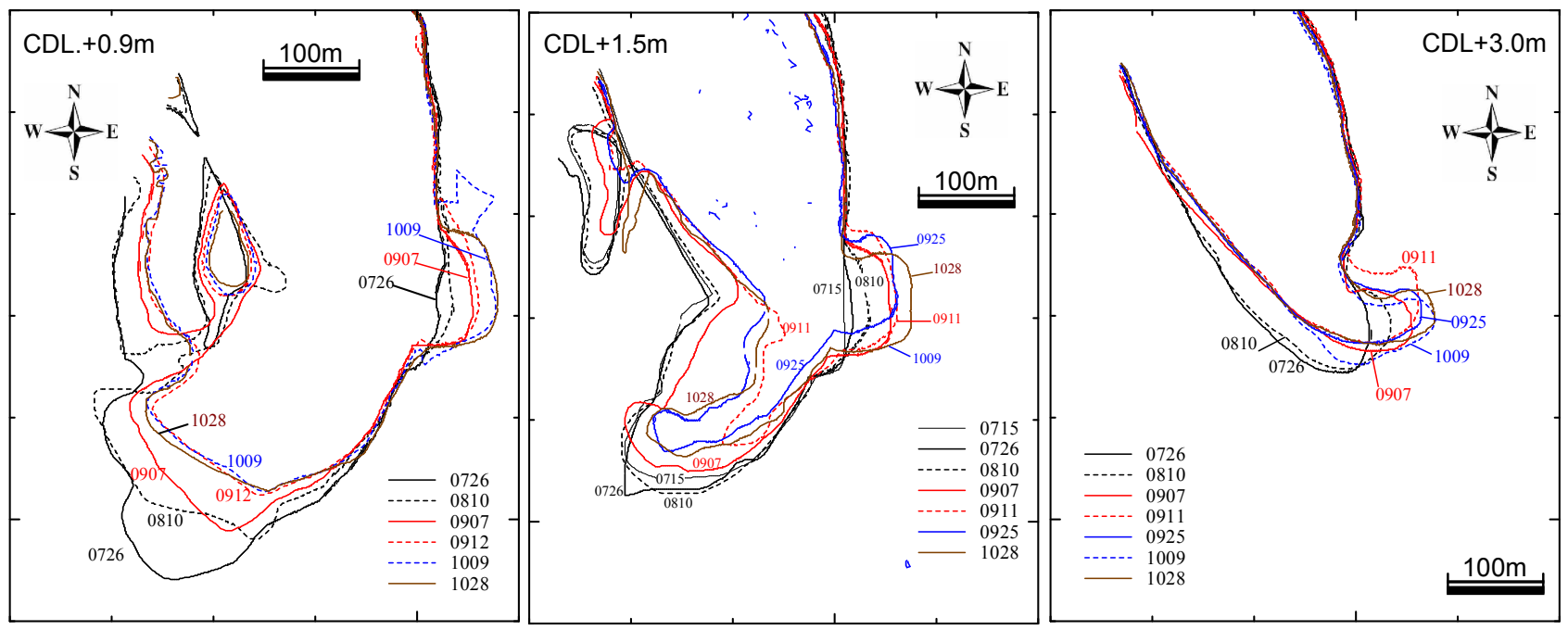

図-7 等深線 $(\mathrm{CDL}+0.9 \mathrm{~m}, 1.5 \mathrm{~m}, 3.0 \mathrm{~m})$ 位置の時間変化

得られた等深線図は, 標高差 $2.1 \mathrm{~m} \sim 2.7 \mathrm{~m} の$ 地形を立 体的に捉えることができることになる。このような 条件の下, 本研究で対象とした 3 力月半の間に選定 できた等深線図は，図-5の赤線に示した 8 日分の等 深線図を作成することができた。ただし，たとえば 図-6中の 7 月 15 日の等深線図ではCDL $+0.9 \mathrm{~m}$ 等深線 が図示されていないが，これは7月15日の潮位が CDL+0.9mまでは下がらなかったためである。このよ うに, 得られる等深線の数や標高範囲は潮位変動の 条件によって限定されてしまうものの, 本研究で構 築した手法を用いることにより, 河口部の砂州周辺 地形を比較的容易に, かつ, 高頻度に捉えることが 可能になったと言える.

\section{5. 外力場と砂州変形の関係}

図-6に加え，等深線位置の時間変化をより明確に 示寸ため, $C D L+0.9 \mathrm{~m}, 1.5 \mathrm{~m}, 3.0 \mathrm{~m}$ 等深線に着目し, これらの等深線位置の時間変化を図-7に示す.ここ では，砂州周辺地形の変化を示した図-6および図-7, さらに観測時の外力条件を示した図-5に基づき，島 田川河口砂州の変形特性を以下に考察する.

まず対象期間中の外力場について整理する. 定点 観測カメラおよび水圧式波高計を設置した7月15日 直前には, 当該地点における日降雨量が年間を通じ て最大となる小規模な出水があった，その後，来襲 波浪場も静穏で, かつ河川流量も小さい日が8月末 まで続いた。9月初旬には台風9号の来襲に伴い島田 川河口部周辺でもやや大きな波浪が来襲した。ささら に9月下旬には日降水量 $60 \mathrm{~mm}$ 程度の雨が降り, 河川 流量がやや増大した。10月にはやや大きい波浪が来 襲した。

次に, 図-6に基づき砂州地形の特性について考察 する. 図に見られるように砂州は南東方向に伸び, 先端部の南東側が開口部で河川流は南西方向へと流 出する. 砂州周辺地形は平均潮位にあたる $\mathrm{CDL}+2 \mathrm{~m}$ 周
辺より高い地点では等高線が接近し急勾配となるの に対し, それより標高の低い地点では, 特に砂州の 海側 (南西側) で, 等深線の間隔が急激に広く, 寸な わち，勾配が極めて緩やかになっているのが分かる。 一方, 開口部にあたる砂州先端の南東側では, 標高 によらず等深線の間隔が狭く, 急激に水深が深く なっているのも特徵的である.

次に河口砂州地形の時間変化について考察する. まず7月中旬の出水直後から, 台風9号が来襲する直 前の9月7日までの変化に焦点をあてる. 図-7に示し たCDL+0.9m等深線の海側領域での時間変化に着目す ると，この期間では南西に大きく張り出した等深線 領域が大きく縮小している。 また同様にCDL+1.5mの 等深線も, 海側 (南西側)に張り出した領域が大きく 縮小している．特に北西側での縮小が顕著であるこ とから, 出水時に開口部沖側へと流出して堆積した 土砂の多くは，沿岸方向 (北西方向) 一と運ばれたと 推察される. また同様にCDL+3.0m等深線においても， 先端部南西側 (海側) の等深線は台風9号が来襲する 直前の 9 月 7 日まで徐々に後退している様子が分かる. このCDL+3. $0 \mathrm{~m} の$ 海側等深線の変化も, 先端部のみで 南西からの来襲波浪に対寸る法線方向角度と小さく する方向に変化しており, 前述した海側領域におけ る北西方向への沿岸漂砂移動による地形変化が卓越 的であったとする推察と矛盾なく整合していると言 える。

次に台風 9 号来襲の前後にあたる9月 7 日と 9 月 11 日 での等深線変化に着目する. CDL $+0.9 \mathrm{~m}$ 等深線では, この期間に大きく上流方向に等深線が移動するもの の, その後は特に海側等深線形状が安定する傾向が 見られた。一方CDL+1.5mの等深線は9月 11 日に海側 で南西方向に張り出した領域が著しく縮小した後, 9月後半から10月にかけては, 再び沖側へと張り出 している. CDL+3.0mの等深線では, 海側の等深線位 置には大きな変化が見られなかったものの, 砂州の 上流側では等深線が大きく上流側 (北向き) に移動し ている. 砂州先端から沿岸方向西向きに離れた海側 
の領域では, 台風来襲時における大きな変化が見ら れないことから，ここで見られた変化は主に波によ る岸向き土砂移動に起因しているものであると推察 される。

台風来襲後の変化に着目する．既に述べたように CDL+0.9mでは，砂州の海側領域では大きな変化は見 られないものの，砂州裏側では押し込まれた先端部 の斜面勾配が緩やかになるのに合わせてCDL+0.9mの 等深線の北東方向へと延伸している。一方, CDL+1. $5 \mathrm{~m}$ の等深線は海側でも上流側でも活発に移動 しており，上流側では北東方向への延伸，海側では 南西方向 (沖向き) への移動が見られる. 特に海側で は台風来襲により岸向きに運ばれた土砂を再び沖向 きに輸送しているようであり，これは台風来襲時に 北向きに押し込まれた砂州先端部が再び南向きに移 動していることと符合している.

\section{5. おわりに}

山口県光市島田川河口部を対象に，定点観測カメ ラおよび水圧式波高計による潮位観測結果に基づき 河口砂州周辺の等深線変化をモニタリング可能なシ ステムを構築した。観測した潮位データに基づき， 特定の潮位条件に対応する画像を選択し, 予め測定 した基準点座標に基づき画像の座標変換を行うこと により, 画像上の任意の点における平面直角座標を 推定した。 また, 定点観測カメラの位置やアングル の微小な変化に伴う座標推定誤差を軽減させるため, 基準画像との画素座標比較による画像修正システム を導入し，画像に基づく平面直角座標の推定精度の 向上を試みた。

島田川における 3 ケ月間の定点観測画像から，8 枚の等深線図を作成し, その変形特性を外力場の変 化と比較した．その結果，主に以下の考察を導くに 至った. 出水により河口開口部の西側で等深線が大
きく張り出し, その後の比較的静穏な常時波浪によ り, 沿岸方向への漂砂移動によるものと推察される 西側領域での等深線の後退が顕著に見られた。台風 9 号来襲時には，岸向きの漂砂移動によるものと推 察される等深線の岸向き方向への顕著な後退が見ら れ，特に砂州先端部は上流側へと大きく押し込まれ た. 台風来襲後は, 水深の小さいCDL+1. $5 \mathrm{~m}$ の等深線 で沖向きへ延伸する変化が見られ，上流方向に押し 込まれていた砂州先端部は再び沖向きへと押し戻さ れた. 一方で比較的水深の大きなCDL $+0.9 \mathrm{~m} の$ 等深線 では台風来襲後には顕著な変化が見られず, 出水直 後からの変化に対し, 常時波浪, 常時河川流量の下 では，ほぼ安定状態に達していたと推察される。

ここで構築した手法を用いることにより，特に潮 位差が大きな地点では, 沿岸域の3次元地形形状の 変化を高頻度に追跡することが可能となる．特に変 化が激しく複雑な河口域などにおいて, より詳細な 外力場の時間変化との詳細な比較を行うことにより, 効果的なモニタリングが行えるようになると期待さ れる。

謝辞：本研究の実施にあたり，山口県光市から計測 機器の設置や許可申請など全面的にご支援いただき ました。また定点観測カメラの設置においては，株 式会社ファノスのご好意により，カメラの設置場所 をご提供いただきました。ここに記して深甚なる謝 意を表します.

\section{参考文献}

1) 田島芳満, 高川智博, 浅野泰史, 佐藤愼司, 武若聡 : 特性の異なる二つの台風による天竜川河口砂州の大規 模変形, 海岸工学論文集, 第 55 巻, pp. 646-650, 2008. 